\title{
Waste Water: Treatment Options and its Associated Benefits
}

\author{
Akuzuo Ofoefule, Eunice Uzodinma and Cynthia Ibeto \\ Biomass Unit, National Center for Energy Research \& Development, \\ University of Nigeria, Nsukka. Enugu state \\ Nigeria
}

\section{Introduction}

Wastewater, a semi-liquid waste that is discharged from residential homes, industries, agricultural and commercial properties potentially release significant amounts of toxic and pathogenic contaminants into local treatment plants for processing. These contaminants include not only soaps, shampoos and conditioners used in showers, food scraps and oils from kitchen sinks and garbage disposals, human waste from toilets, detergents and fabric softeners from washing machines and dishwashers as well as all the harsh detergents that clean the house, but also heavy metals, pharmaceuticals, volatile organic compounds (VOCs), volatile toxic organic compounds (VTOCs), pathogenic microorganisms, phosphorus, nitrogen, substances that are carcinogenic, tetragenic and mutagenic that are resistant to typical wastewater treatment processes that come from industries.

Potable water becomes wastewater after it gets contaminated with natural or synthetic microbiological compounds that arise out of human activities, commercial and industrial sources. They may be accompanied with surface water, ground water and storm water. Wastewater is also sewage, storm-water and water that have been used for various purposes around the community. Unless properly treated, wastewater can be harmful to public health and the environment.

\section{Sources of wastes}

Most communities generate wastewater from both residential and non-residential sources.

\section{Residential Wastewater or Household Wastewater}

Residential wastewater is a combination of excreta, flush water and all types of wastewater generated from every room in a house. It is more commonly known as sewage and is much diluted. There are two types of domestic sewage: black-water or wastewater from toilets, and gray water, which is wastewater from all sources except toilets. Black-water and graywater have different characteristics, but both contain pollutants and disease-causing agents. In the U.S, sewage varies regionally and from home to home. These are based on factors such as the number and type of water-using fixtures and appliances used at homes and even their habits, such as the types of food that are eaten. 


\section{Non-Residential Wastewater or Industrial Wastewater}

This is mainly made up of wastes coming from commercial activities (e.g., shops, restaurants, hospitals etc.), Industry (e.g., Chemical Industries, Pharmaceutical companies, Textile manufacturing companies etc.), Agriculture (e.g., slurry), construction and demolition projects, mining and quarrying activities and from the generation of energy. These could be places such as industrial complexes, factories, offices, restaurants, farms and hospitals. Because of the different non-residential wastewater characteristics, communities need to assess each source individually to ensure that adequate treatment is provided. For example, laundries differ from many other industrial sources because they produce high volumes of wastewater containing lint fibers. Restaurants typically generate a lot of oil and grease. In addition, many industries produce wastewater high in chemical and biological pollutants that, can overburden onsite and community wastewater treatment systems.

Storm-water is a nonresidential source and carries trash and other pollutants from streets, as well as pesticides and fertilizers from yards and fields. Communities may require these types of nonresidential sources to provide preliminary treatment to protect community systems and public health (Runion, 2010).

\section{Environmental hazards of waste water}

Wastewater can attract rodents and insects which cause gastrointestinal parasites, yellow fever, worms, the plague and other unhealthy conditions for humans. Exposure to hazardous wastes, particularly when they are burned, can cause various other diseases including cancers. Wastes can contaminate surface water, groundwater, soil, and air which causes more problems for humans, other species, and ecosystems. Waste treatment and disposal produces significant green house gas (GHG) emissions, notably methane, which are contributing significantly to global climate change.

Disease- causing pathogens are constantly being released into waterways from waste water. However, these chemical substances are only the tip of the iceberg. The pathogens from diseases such as AIDS, cholera, plague, hepatitis, typhoid, polio and so on are also released from homes, medical clinics, laboratories and hospitals. Studies have shown that every gram of fecal material from an infectious hepatitis patient can contain up to 100,000 infectious doses. Other pathogens include cryptosporidium, giardia, neospora, e.coli, stretococcus, legionella, salmonella, shigella, vibrio, adenoviruses, Norwalk, rotavirus, amoeba, whipworm, tapeworms, flukes, pinworms, roundworms, klebsiella, clostridium, pseudomonas and mycobacterium tuberculosis. These microbes are not looked for nor tested in a routine analysis of treated wastewater before their release into the environment.

Many viruses can survive in wastewater up to 41 days at $20^{\circ} \mathrm{C}$. Once released into the environment, they can survive up to six or more days in a river and up to 100 days in soil. The protozoa parasite can survive up to 20 days in soil while bacteria can survive up to 120 days. Most worms like the ascaris, tapeworms and trichuris can survive up to 12 months in soil. Their survival in soil depends on moisture, $\mathrm{pH}$, temperature, type of soil and the presence of organic matter (Anon, 1980). It is estimated that every year 1.8 million people die worldwide due to suffering from waterborne diseases. A large part of these deaths can be indirectly attributed to improper sanitation. Wastewater treatment is an important initiative which has to be taken more seriously for the preservation of society both at present and in the future.

Also, Mills discharge millions of gallons of effluent each year, full of chemicals such as formaldehyde (HCHO), chlorine, heavy metals (such as lead and mercury) and others, which are significant causes of environmental degradation and human illnesses. The mill effluent is 
also often of a high temperature and $\mathrm{pH}$, both of which are extremely damaging. All of the mills $\mathrm{O}$ Ecotextiles (A producer of high quality organic fabrics in Seattle, Washington) uses, have wastewater treatment in place. Every 25 meters of an O Ecotextiles sofa fabric prevents 2,300 liters of chemically infused effluent(about the size of a California hot tub and containing from 1 to $10 \mathrm{~kg}$ of toxic chemicals), from entering the environment (Based on VPI study for Dept. of Environmental Quality for the state of Virginia.) (Anon, 2005).

\section{Some advantages of waste water and its treatment}

Oboh (2005) studied the utilization of fermented waste water from cassava mash as source of industrial amylase and reported that the amylases from fermented cassava waste water are active at wide temperature and $\mathrm{pH}$ ranges. This quality could be explored in the industrial sector (most especially food industry) as a source of industrial amylase.

Wastewater treatment is a process whereby the contaminants are removed from wastewater as well as household sewage, to produce waste stream or solid waste suitable for discharge or reuse (Naik, 2010). Treated wastewater is now being considered as a new source of water that can be used for different purposes such as agricultural (70\% of Israel's irrigated agriculture is based on highly purified wastewater) and aquaculture production, industrial uses (cooling towers), recreational purposes and artificial recharge. Using wastewater for agricultural production will help in alleviating food shortages and reduce the gap between supply and demand. Treated wastewater can be re-used as drinking water, in artificial recharge of aquifers, in agriculture and in the rehabilitation of natural ecosystems (Florida's Everglades).

Re-use of wastewater, in concert with other water conservation strategies, can help lessen anthropogenic stresses arising from over-extraction and pollution of receiving waters. However, there are concomitant environmental risks with wastewater re-use, such as transport of harmful contaminants in soils, pollution of groundwater and surface water, degradation of soil quality e.g. salinization, impacts on plant growth, the transmission of disease via the consumption of wastewater-irrigated vegetables, and even increased greenhouse gas emissions. The challenge facing wastewater re-use is to minimize such risks so as to maximize the net environmental gain.

There are more than 150 known pathogens detected in untreated wastewater. Every year new ones are being discovered. Of the 72 enteroviruses, many will trigger illnesses that are not gastrointestinal, such as, polio, meningitis, diabetes, muscle diseases and endocarditis (inflammation of the heart muscle that can lead to heart attacks). They can and do produce infectious illnesses in humans that multiply and are re-excreted through fecal material (Mara and Horan, 2003), hence, the need for waste water treatment in order to avoid the occurrence of such pathogens in the environment.

\section{Benefits of treatment on man and the environment}

Endocrine disruptors, also known as xenoestrogens, are chemical compounds and byproducts used in the plastic, pesticide and chemical industries and found in their waste water that have hormonal effects on the body. There are more than 100,000 registered endocrine disruptors. They are far more potent in mimicking estrogen activity than the body's natural hormones and far more toxic. The synergistic effects of these chemicals in the body may be up to 1000 times greater. Endocrine disruptors create a large range of reproductive problems. They include infertility, menstrual problems, difficulty holding a pregnancy to term and early puberty. Other health issues include impaired immune function, behavioral problems, brain malfunctions and cancer (Anon, 1995). 
Waste water quality deteriorates rapidly and causes microorganisms, protozoa, fecal coliform, and fecal streptococci in the surrounding area. It is affected directly by the quality of groundwater in the area mainly with surfactants such as Anionic Detergents (linear alkyl sulphonate, LAS) and nitrite in the surrounding area around the infiltration basins with cycle diameter of $800 \mathrm{~m}$. This is very harmful to the human body and cause gastroenteritis troubles.

\section{Wastewater Treatment}

Wastewater treatment is the removal of solids, bacteria, algae, plants, inorganic and organic compounds from used water with subsequent conversion into environmentally acceptable water or even drinking water. This treatment usually requires science, engineering, business and art (Anon., 2010) and includes mechanical, physical, chemical and biological methods. Most often, huge amount of waste water is generated from various sources; domestic, municipal and industrial activities. The waste water may be characterized with $\mathrm{pH}$, suspended solids (SS) dissolved solid (DS), turbidity, colour, biological oxygen demand (BOD) and chemical oxygen demand (COD) among others. Each source of the water has its own pollution problem and must be treated to return water to its natural state or re-used in various activities. Waste water treatment can be grouped in three major ways: physical, chemical and biological treatment. Physical treatment involves processes such as sedimentation, aeration, filtration and floatation while chemical treatment uses oxidizing agents such as chlorine, ozone, including neutralization method. Sometimes coagulants like alum, iron (III) sulphate, among others could be utilized. Carbon could be used both in chemical and physical methods as adsorbent. In the biological water treatment, microorganisms such as bacteria are biochemically employed to decompose wastewater to produce water stable product. There are aerobic and anaerobic decomposition. Under aerobic decomposition, contaminants in water are converted to carbon dioxide while anaerobic decomposition produces methane as a fuel in biogas and carbon dioxide as major products. The effluent from anaerobic process can be used as manure in agricultural production. (Anon, 2010).

\section{The Importance/need for Waste water Treatment}

Population explosion, disorderly rapid movement to the urban areas, technological and industrial expansion, energy utilization and waste generation from domestic, municipal and industrial sources have rendered many waters unwholesome and hazardous to man and other living things. There are no stringent laws guiding environmental pollution in most developing countries in the world. Consequently, industries discharge untreated or inadequately treated water into water ways (Amuda and Ibrahim, 2006). Most of these waters pose great dangers to aquatic life and must be cleaned or treated.

\section{Reported Researches on Wastewater Treatment Methods}

Treatment processes for heavy metals removal from wastewater include precipitation, membrane filtration, ion exchange, adsorption and co- precipitation/adsorption. Studies have shown that adsorption method is highly effective and activated carbon has been in use but very expensive (Nasim et al., 2004). Amuda and Ibrahim (2006), reported on the comparison of adsorption efficiency of coconut shell- based activated carbon and commercial activated carbon calgon, carbon (F-300) in the treatment of industrial wastewater from a beverage industry for the removal of organic matter (COD). The results of their findings indicated that coconut shell- based granular activated carbon was found to effectively adsorb the organic than the commercial activated carbon. Besides, previous 
researches on the removal of COD from industrial wastewater using coagulation/flocculation, membrane filtration and oxidation processes etc., reveal that the technology of these methods are generally expensive, complicated, time consuming and required skilled personnel (Galambos et al., 2004; Peres et al., 2004). However, low cost and non-conventional adsorbents such as nut shells, wood, bone, peat, processed into activated carbons and biomass such as Aspergillum tereus, Peusodomonas sp., Rhizopus arrhizus are better (Okieimen et al., 1985; Tam and Antal, 1999; Bansode et al.,2004; Nomanbhay and Palanisamy, 2005; Preetha and Viruthagiri, 2005). Again, ultraviolet (UV) lamp has also been used to treat textile wastewater. Stanislaw and Monica (1999), reported the application two different UV radiations; $150 \mathrm{~W}, \lambda=254-578 \mathrm{~nm}$ and $15 \mathrm{~W}, \lambda=254 \mathrm{~nm}$ to the synthetic textile wastewater for $1-3 \mathrm{~h}$. There was significant inhibitory action on the microbes (47 to $30 \%$ reductions) for the optimum radiation time. Moreover, ozone $\left(\mathrm{O}_{3}\right)$ is a powerful oxidant for both water and wastewater. The conventional fine bubble contactor is the most widely used Ozone generator because of high Ozone transfer efficiency (90\%). Result of findings from Mehmet and Hassan (2002), showed that ozonation using $300 \mathrm{mg} / \mathrm{dm}^{3}$ gave rise to biodegradability index of textile wastewater by 1.6times. Few researchers namely; Namboodri et al., (1994); Rajeswari (2000) among others revealed that ozone decolourizes all dyes except non-soluble dispersed and vat dyes that react slowly and take longer time. Hence, ozone was combined with other agents for its complete oxidation of organic compounds in the wastewater to carbon dioxide and water. This combination has led to advanced oxidation processes using ozone and others, e.g.--- $\mathrm{O}_{3} / \mathrm{UV}, \mathrm{O}_{3} / \mathrm{H}_{2} \mathrm{O}_{2}, \mathrm{O}_{3} / \mathrm{TiO}_{2}$, etc. Xuejun et al., (2005), used a combination of electrochemical oxidation combined with membrane filtration to treat wastewater from a textile industry. Results obtained showed that electrochemical oxidation has a high removal of $89.9 \%$ efficiency of COD of wastewater whereas the membrane filter can almost completely remove total suspended solids (about $100 \%)$ and turbidity (98.3\%). After electrochemical and membrane filtration steps were employed, COD levels were reduced to $18.2 \mathrm{mg} / \mathrm{L}$ from $178.5 \mathrm{mg} / \mathrm{L}$. Turbidity was reduced from 18.5 NTU to 0.32 NTU. Oparaku et al., (2011) reported on disinfection of wastewater from fish pond for re-utilization using ultraviolet radiations. The UV treated wastewater had lowest coliform count of $1.8 \times 10^{3} \mathrm{Cfu} / \mathrm{ml}$ in comparison with solar and electric powered pump water counts obtained as $2.2 \times 10^{3}$ and $6.8 \times 10^{3} \mathrm{Cfu} / \mathrm{ml}$, respectively. This treated water also had dissolved oxygen that amounted to $7.2 \mathrm{mg} / \mathrm{L}$, averagely favourable for aquatic life. Moreover, anaerobic digestion has been utilized to convert municipal wastewater (MSW) into methane and carbon dioxide with the effluent used as biofertilizer. Chynoweth et al., (1991), presented the results of biochemical potential of several fractions of MSW in order to compare the extent and rates of their conversions to methane. It was discovered that the methane yield was as high as $0.20 \mathrm{~m}^{3} / \mathrm{kg}$ of volatile solids added. A report from Okafor (1998) showed that cassava wastewater generated from "garri" production (a staple food consumed in the Eastern part of Nigeria), was inoculated with microorganisms to produce microbial biomass. This biomass was then mixed with ground cassava peels to formulate feed for pigs. Droppings from the pigs were later converted to biogas through anaerobic digestion. Again, implementation of anaerobic process on wastewater from tapioca starch industries has been reported. The research results showed that the value of organic substance in the influent were in the average of 10, 062 and 5,649 ppm in terms of COD and BOD, respectively. Maximum organic loading rate applied was $7.8 \mathrm{~kg} \mathrm{COD} / \mathrm{m}^{3}$ day. The efficiency of degradation reached an average of $76 \%$ and $95.8 \%$ for COD and BOD, respectively. Methane content in the biogas was in the range of 53.5 to $71 \%$ while average biogas production was $1.2 \mathrm{~m}^{3} / \mathrm{m}^{3}$ of wastewater. 


\section{Anaerobic digestion as a waste water treatment option}

Anaerobic digestion (AD) is biological process similar in many ways to composting. It is a natural treatment process and as in composting bacteria in the absence of air, breakdown organic matter and reduce its bulk or mass (polymers) into simpler compounds mainly methane $\left(\mathrm{CH}_{4}\right)$ and carbon IV oxide $\left(\mathrm{CO}_{2}\right)$ and traces of other gases like $\mathrm{O}_{2}, \mathrm{H}_{2} \mathrm{~S}, \mathrm{NH}_{3}, \mathrm{~N}_{2}$, $\mathrm{CO}$ and water vapour etc (Wolfgang and Axel, 2005). The effluent of this process is a residue rich in essential inorganic elements like nitrogen and phosphorus needed for healthy plant growth known as biofertilizer which when applied to the soil enriches it with no detrimental effects on the environment (Bhat et al., 2001).

Anaerobic waste digestion Takes place in a closed reactor. Bacteria act upon the organic waste and release a lot of methane and carbon dioxide. The microbial community has only obligate anaerobic and facultative bacteria. As in aerobic chemohetrotrophic metabolism, initially the macromolecules are hydrolyzed. These products are then converted to volatile fatty acids (mainly acetic acid), and alcohols. The organisms responsible for these anaerobic waste reactions are popularly called acid formers or acidogens. They obtain energy through oxidation of organic compounds, but do not use oxygen as electron acceptor. Instead, another fragment of the substrate is reduced to anaerobic acids and alcohols through anaerobic processes. These are then metabolized by a second group of obligate anaerobic biomass (the methane formers or methanogens), and are converted to methane gas. It is estimated that 60 to $70 \%$ of methane production in an anaerobic waste reaction is through conversion of acetic acid and the rest through carbon dioxide reduction by hydrogen. The activities of the methane and acid- producing groups of bacteria must be balanced as the former is sensitive to $\mathrm{pH}$ changes and works best in $\mathrm{pH}$ range 6.8 to 7.5. (Runion, 2010).

$$
\begin{gathered}
\left(\mathrm{C}_{6} \mathrm{H}_{10} \mathrm{O}_{5}\right) \mathrm{n}+\mathrm{nH}_{2} \mathrm{O} \rightarrow \mathrm{n}\left(\mathrm{C}_{6} \mathrm{H}_{12} \mathrm{O}_{6}\right)-\text { Hydrolysis } \\
\mathrm{n}\left(\mathrm{C}_{6} \mathrm{H}_{12} \mathrm{O}_{6} \rightarrow \mathrm{nCH} \mathrm{COOH}_{3} \mathrm{C}\right. \text { Acetogenesis / Acidogenesis } \\
\quad 3 \mathrm{nCH}_{3} \mathrm{COOH} \rightarrow \mathrm{nCH}_{4}+\mathrm{CO}_{2}-\text { Methanogenesis }
\end{gathered}
$$

The objectives for planning an anaerobic digestion process include

1. To provide waste regulations compliant, sustainable and cost effective method of disposal of organic wastes

2. To treat, clean source separated organic wastes from households, restaurants, industries and other enterprises in an environmentally friendly manner.

3. To provide a sustainable and cost effective method of disposal of ABPR waste materials

4. To reduce carbon emissions and carbon levies payable associated with a business.

5. To establish a sustainable circulation of plant nutrients and organic material between the community and agricultural sector in such a way that the use of the residual is optimized.

6. To provide opportunities for the use of artificial fertilizer (i.e. promote organic farming).

7. To extract and use high grade bio-energy from waste and normal farm crops, with no net contribution to the atmosphere.

8. To promote and develop high efficiency energy processes and remove odours generated from present systems.

9. To reduce risk of water pollution from current practices and generally reduce emissions of enteric organisms and water courses. 
Environmental technologists have in the last decade been concerned with straight forward technological, economic challenges such as drinking water production, waste water treatment, refuse handling and treatment, soil and sediment clean-up and waste gas purification. Only recently, they have started to look at their activities from the point of view of sustainability and they have had to admit that in many cases, they were far from holistic (Verstraete and Top, 1992).

Typical examples of non-sustainable approaches are current practices in anaerobic waste water treatment and refuse land filling (Allison-Onyechere et al., 2007). Lettinga et al., 1980 and Verstraete et al., 1996 reported the development of anaerobic sludge blanket or UASB reactor for the treatment of waste water. In this process, the waste water is pumped upwards through a reactor under strictly anaerobic conditions at a rate between 0.5 and $1.5 \mathrm{~m} / \mathrm{hr}$. Inside the reactor, a selection process occurs which can result in the growth of anaerobic micro-organisms in kind of conglomerate (granules) varying between $0.5-5 \mathrm{mg}$ in diameter. These granules are powerful biocatalysts and convert the biodegradable organic matter in the influent in a rapid (space loadings varying from $10-20 \mathrm{~kg}$ chemical oxygen demand (COD) $/ \mathrm{m}^{3} /$ reactor/day) and complete way to biogas. Actually, the granular biomass is such a valuable biocatalyst that it is the only mixed culture which is commercially handled world wide at a respectful price of the order of about 1-2USD per Key dry weight. The sludge is separated from the water and the gas phase by means of an internal settler. Generally effluents approaching discharge standards are thus obtained from waste waters from breweries and soft drink plants, from potato processing plants and from certain paper recycling plants.

For concentrated waste waters, an aerobic treatment has to succeed the anaerobic treatment, yet in a similar and less energy consuming manner. At present, several hundreds of UASB reactors have been installed worldwide, particularly to treat industrial waste water with a COD exceeding 2.0 grams per litre (g/l). They are generally implemented when the waste water is rich in carbohydrates and relatively poor in other contaminants (Allison-Onyechere et al., 2007). For tropical countries, direct anaerobic treatment of sewage has become a reality and several full scale systems are currently operated in Columbia, Brazil and India (Van Haandel and Lettinga, 1994). This is a channel that must be explored further in terms of additional sun-heat input (e.g by means of solar heating systems) and nutrient removal by means of nutrient immobilizing straw biofilter as reported by Avnimelech et al., 1993.

\section{Anaerobic digestion of water slurries}

The authors have carried out anaerobic digestion of different waste waters / slurries and they are highlighted below;

\section{Methodology}

\section{Wastes procurement}

The wastes used for the anaerobic digestion studies discussed below, which invariably were the wastes to be treated were generally procured or collected from the locality. For instance, the cassava waste waters were collected from local processors of "garri" (a staple food consumed in the eastern part of Nigeria). The palm oil sludge was collected from local processors of palm oil in the community. The cow liquor waste was collected from an abattoir in the locality while the Brewery spent grain and carbonated soft drink sludge were 
obtained from Nigerian Breweries Ltd and 7UP bottling company (a soft drink manufacturing company) all around the locality. The swine dung were collected from the Veterinary farm in the University of Nigeria, Nsukka.

\section{Waste preparation}

Since the primary focus of the different studies were on cheaper sources of energy generation while secondarily obtaining waste effluents that are not only harmless to the environment but expected to boost organic farming/Agriculture, some of the waste waters were pretreated with other solid organic wastes to improve on their biogas production potentials. For instance,

1. In one study, cassava waste water (CW) was co- digested with swine dung (SD) in the ratio of 2:1 while the CW alone and SD alone served as control (Ofoefule et al., 2010).

2. In another study, Abattoir cow liquor (CLW) was combined with brewery spent grain (BS) in the ratio 1:1, cassava waste water (CW) in the ratio 1:3 and carbonated soft drink sludge(CS) in the ratio 3:1 (Uzodinma and Ofoefule, 2008).

3. In yet another study, palm oil sludge (POS) was blended with Agro-industrial wastes like cassava waste water (CW), Brewery spent grain (SG) and carbonated soft drink sludge (SL) in ratios of 1:1, 1:1, and 1:1.2 respectively (Uzodinma et al., 2007a).

4. In yet another study, cassava waste water (CW) was combined with palm oil sludge (POS) in the ratio 2:1, powdered rice husk (RH) 1:2.3 and pig dung (PD) 1:1.5. The nature of the wastes determined their combination ratios (Uzodinma et al., 2007b).

\section{Non- waste materials}

Other materials used in the studies generally included; metallic prototype biodigesters/fermenters ranging from 50L capacity (Fig. 1) to 136L capacity (Fig. 2) fabricated locally at the National Centre for Energy Research and development, University of Nigeria, Nsukka. Other materials also used were; Top loading balance (50kg capacity "Five goats" model no Z051599), plastic water troughs, graduated transparent plastic buckets for measuring daily gas production, digital $\mathrm{pH}$ meter (Jenway 3510), thermometer ($\left.10-110^{\circ} \mathrm{C}\right)$, hosepipes, biogas burner fabricated locally for checking gas flammability.

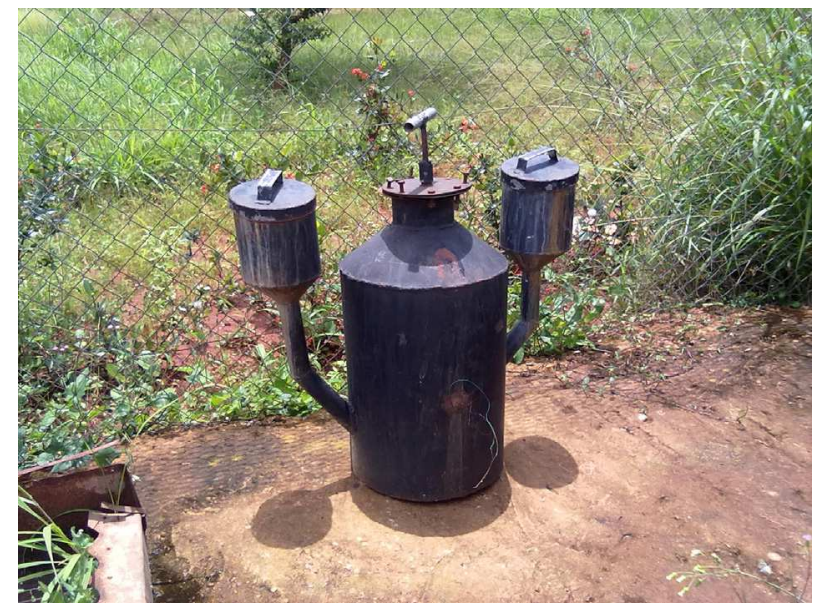

Fig. 1. 50L Capacity Metallic Prototype Biodigester 


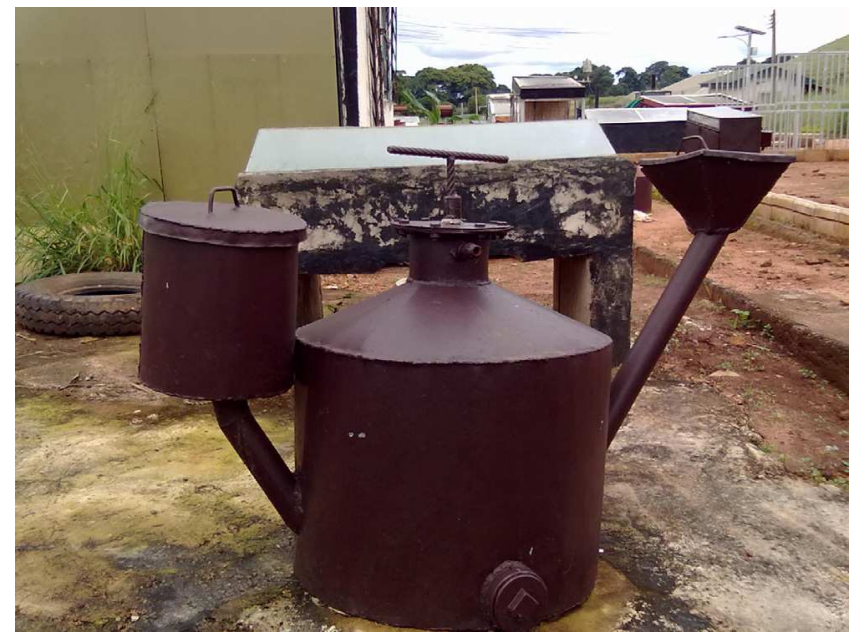

Fig. 2. 136L Capacity Metallic Prototype Biodigester

\section{Experimental studies}

The wastes were generally mixed with water in the ratio of 2:1 except in the cases where the wastewaters were used alone as control. In such instances, the waste waters were used as they were without further dilution since the constituents were mainly water (93-95\%). The digesters were charged up to $3 / 4$ level leaving $1 / 4$ head space for gas collection. They were stirred thoroughly and on a daily basis throughout the retention period to ensure homogenous blend of the wastes and dispersion of microbes in the entire mixture. Gas production measured as $\mathrm{dm}^{3} / \mathrm{kg}$ slurry or L/Total mass of slurry were obtained by downward displacement of water by the gas.

\section{Analyses of wastes}

Physicochemical properties of the wastes such as ash, moisture, crude fibre contents, crude fat, crude nitrogen and protein contents, carbon, energy, total and volatile solids were generally determined for all the wastes using recognized laboratory procedures. These properties inherent in the wastes determine and explain the behavior of the wastes during anaerobic digestion. Biochemical analyses such as $\mathrm{pH}$, ambient and influent temperatures were also monitored on the waste slurries as the digestion of the waste progressed. Microbial analysis was also carried out to determine the microbial total viable counts (TVC) for the waste slurries at different periods during the digestion; at the point of charging the digester, at the point of flammability, at the peak of gas production and at the end of the retention period. In some cases flammable gas composition from the different wastes were also analyzed.

\section{Results and discussion}

The various results obtained during each of the studies are as itemized below:

\section{Anaerobic batch co-digestion of cassava waste water and Swine dung}

The cassava waste water alone had the highest yield of biogas production $\left(130 \mathrm{dm}^{3} /\right.$ Total mass of slurry) even though the gas produced was not flammable throughout the retention 
period and therefore does not meet the desired need for cooking and lighting but would however be okay for the purposes of ordinary treatment of the waste water. The non flammability of the gas produced was attributed to the acidic nature of the waste. The microbes that convert wastes to biogas are $\mathrm{pH}$ sensitive and survive optimally within the $\mathrm{pH}$ range of 6.5-7.5 (Runion, 2009). It was observed that the fresh cassava waste water kills plants in the farm. However when subjected to anaerobic digestion for a period of 30 days it can then be used in the farms as a good organic fertilizer for agriculture. The CW and SD (cassava waste water and swine dung blend) had a lower yield of 120L/total mass slurry; however it commenced flammability on the $10^{\text {th }}$ day. The swine alone had a yield of 123 L/Total mass slurry and commenced flammability on the $6^{\text {th }}$ day. The results showed that the animal waste had a positive effect on the cassava waste water since the $\mathrm{CW}$ on its own did not produce flammable gas. There was also attendant reduction in the foul odour of the waste after the digestion showing that the anaerobic digestion killed most of the pathogens responsible for the foul odour. Fig 3 shows the daily biogas production for the period, while Table 1 shows the lag period, cumulative and mean volume of gas productions. The lag period is the period from charging of the digester to onset of gas flammability (Ofoefule et al., 2010).

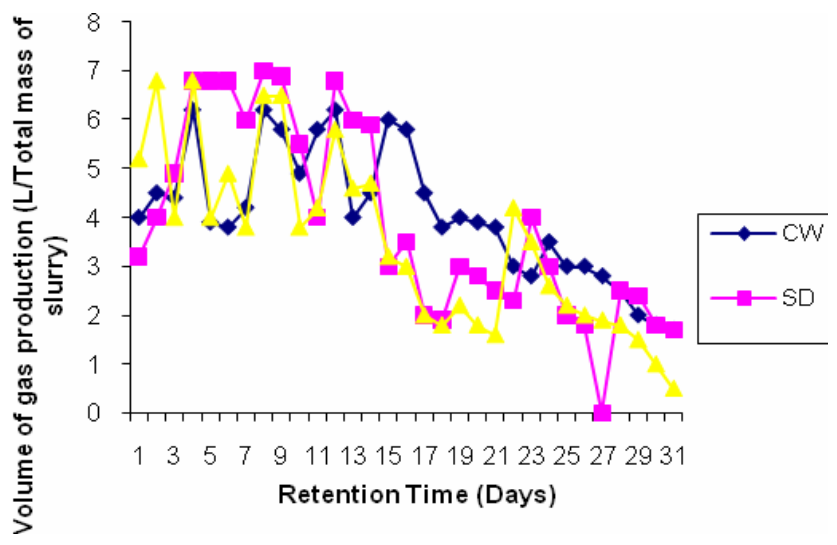

Fig. 3. Daily biogas production

\begin{tabular}{|l|c|c|c|}
\hline PARAMETERS & CW & SD & CW : SD \\
\hline Lag period (days). & Nil & 5 & 9 \\
\hline Cumulative gas yield (L/ total mass of slurry). & 130.25 & 122.55 & 119.90 \\
\hline Mean gas yield (L/ total mass of slurry). & $4.20 \pm 1.32$ & $3.95 \pm 2.01$ & $3.87 \pm 1.80$ \\
\hline
\end{tabular}

Table 1. Lag period, Cumulative and mean volume of gas production of the pure wastes and blend

2. Effect of Abattoir cow liquor waste on biogas yield of some Agro-Industrial wastes.

The results in this study showed that the cow liquor waste and cassava waste water blend (CLW: CW) did not flame throughout the retention period as a result of the acidic nature of the combined waste $(\mathrm{pH}=3.3)$. The carbonated soft drink sludge that commenced flammable biogas production on the $9^{\text {th }}$ day stopped after one and half weeks as a result of the drop in $\mathrm{pH}$ from 5.68 to 5.20. The reduction in $\mathrm{pH}$ killed the microbes responsible for converting the 
waste to biogas. However the CLW: BS (cow liquor waste: brewery spent grain) had the shortest onset of gas flammability and highest cumulative gas yield of 613.2 L/TMS (Table 2). Fig 4 shows the daily biogas production (Uzodinma and Ofoefule, 2008).

\begin{tabular}{|l|c|c|c|c|c|c|}
\hline Parameters & BS & CS & CW & CLW : BS & CLW: CW & CLW: CS \\
\hline Lag period (days) & 20 & 8 & Nil & 6 & 9 & 8 \\
\hline Cumulative gas yield (L/TMS) & 183.6 & 177.50 & Nil & 613.2 & 394.2 & 87.4 \\
\hline $\begin{array}{l}\text { Mean Volume of gas yield } \\
\text { (L/TMS) }\end{array}$ & 7.34 & 7.10 & Nil & 24.53 & 8.23 & 2.54 \\
\hline
\end{tabular}

Table 2. Lag periods, cumulative and mean volume of gas yield for single organic wastes and CLW blends

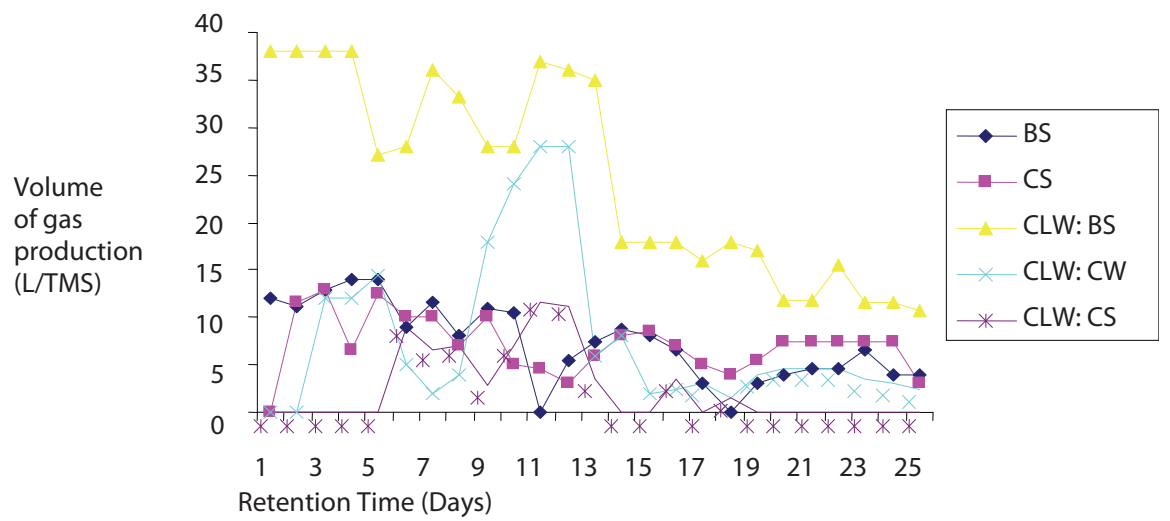

Fig. 4. Daily biogas yield

\section{Preliminary studies on biogas production from blends of palm oil sludge with some Agro-based wastes.}

The palm oil sludge (POS) in this study could not produce quantifiable gas within the 25 days retention period used for the experiment. However when combined with brewery spent grain (SG), carbonated soft drink sludge (SL) and cassava waste water (CW), reasonable quantities of biogas were produced which flamed after some lag periods as shown in Table 3. The POS: CW had the highest yield of biogas followed by the POS: SG while the least yield came from the POS:SL. The better yield of POS: CW over the others could be accounted for by the fact that the $\mathrm{CW}$ and others were allowed to be partially decomposed for a period of two months to increase their $\mathrm{pH}$ level, since in their fresh state they were found to be acidic. This resulted in the cassava waste water giving a better yield of biogas. Analysis of their flammable gas composition showed that POS: CW and POS: SL gave higher methane contents than POS: SG (Table 4). Fig. 5 shows the Daily biogas production (Uzodinma et al., 2007a).

\begin{tabular}{lccc}
\hline Parameters & POS:SG & POSL:CW & POS:SL \\
\hline Lag period (days) & 10 & 8 & 15 \\
Cumulative gas yield (L) & 312 & 394.2 & 87.4 \\
Mean volume of gas yield (L) & 12.5 & 15.8 & 3.5 \\
\hline
\end{tabular}

Table 3. lag periods, cumulative and mean volume of gas yield for POS blends 


\begin{tabular}{lcccc}
\hline Waste blends & $\mathbf{C O}_{\mathbf{2}}$ & $\mathbf{C O}$ & $\mathbf{H}_{\mathbf{2}} \mathbf{S}$ & $\mathbf{C H}_{\mathbf{4}}$ \\
\hline POS:SG & 25.3 & 5.0 & 2.5 & 67.2 \\
POS:CW & 20.9 & 1.6 & 1.3 & 76.2 \\
POS:SL & 20.1 & 1.2 & 2.2 & 76.5 \\
\hline
\end{tabular}

Table 4. Analysis of flammable gas composition for POS blends (\%)

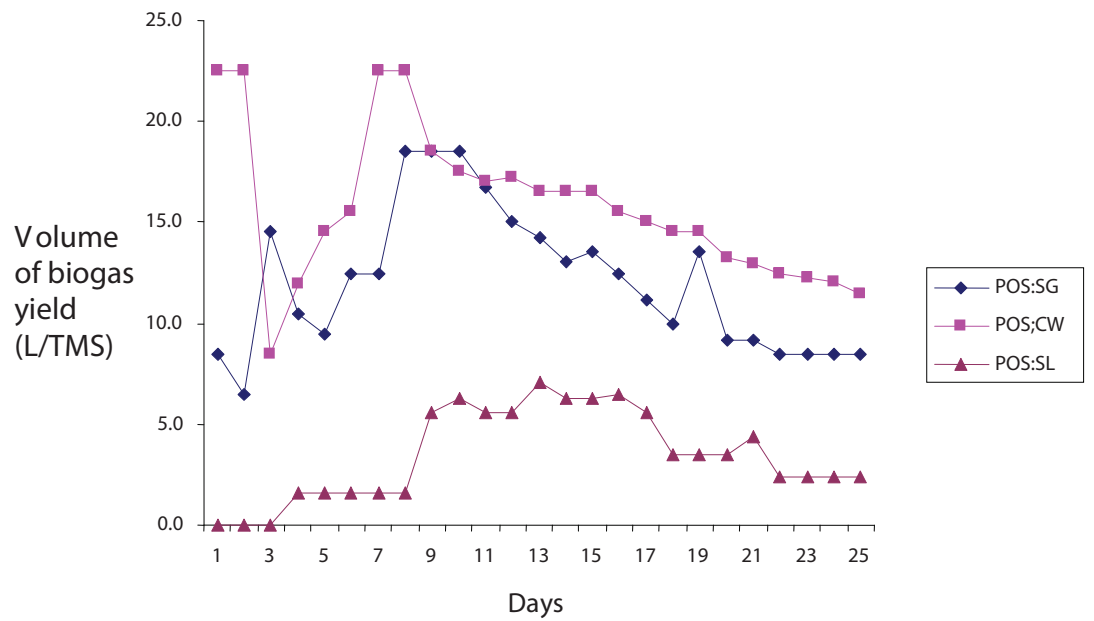

Fig. 5. Daily biogas yield for POS blends

4. Energy generation from microbial conversion of Treated cassava waste water from garri processing industry.

In this study, cassava waste water $(\mathrm{CW})$ was treated with some other wastes to improve its $\mathrm{pH}$ level before digesting it. The waste used included; palm oil sludge (POS), powdered rice husk (RH) and pig dung (PD). The results showed that not only was the $\mathrm{pH}$ increased, the physicochemical properties also improved, which translated to higher biogas yields. The CW: RH gave the highest yield while the CW: PD followed with the shortest lag period of 4 days (Table 5). The higher yield of CW: RH was attributed to the fact that the rice husk was pre-decayed for about 1 month, and as a result had accumulated some microbes that aided in the faster digestion. The shortest lag period of CW: PD was explained by the fact that swine dung is a rumen animal, having the natural flora that are responsible for biogas production in its gut, aiding the fastest onset of gas flammability. Fig. 6 shows the Daily biogas production (Uzodinma et al., 2007b).

\begin{tabular}{|l|c|c|c|}
\hline Parameters & CW:POS & CW:RH & CW:PD \\
\hline Lag period (Days & 8 & 6 & 4 \\
\hline Cumulative volume of gas Production (L/TMS) & 394.20 & 481.30 & 432.00 \\
\hline Mean volume of gas production (L/TMS) & 15.77 & 19.30 & 17.30 \\
\hline
\end{tabular}

Table 5. Lag Period, Cumulative and Mean volume of biogas production 

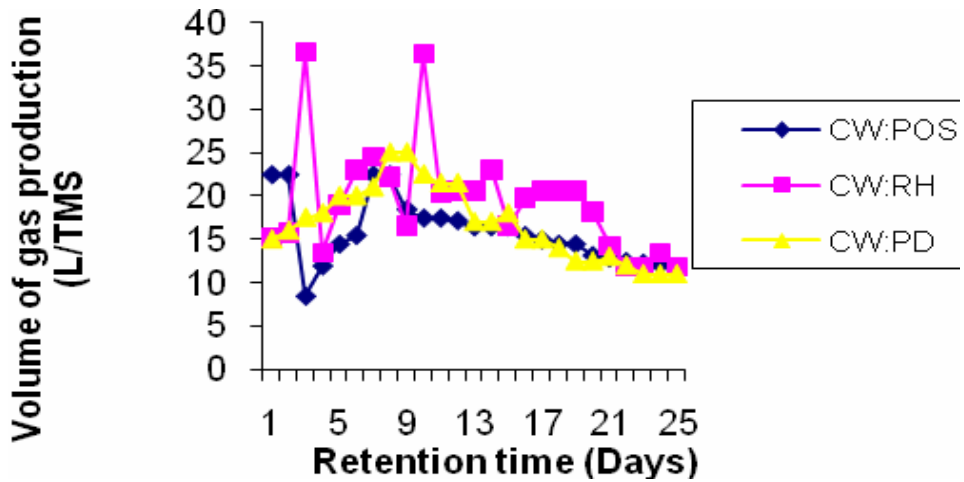

Fig. 6. Daily biogas production

\section{Socio-Economic Benefits of Waste Water Treatment}

Apart from reduction in environmental pollution from the treatment of waste waters, new demands for agricultural products arising from increased biomass usage would impact on the social-economic life of the populace especially when anaerobic digestion process of waste water treatment option is undertaken. Social issues such as employment generation, and poverty reduction especially for the developing countries would be addressed through this technology as a result of expanded economic activities across the real sector of the economy encompassing agriculture, manufacturing and exports. These would enhance people's ability to develop economic activities designated to reduce poverty particularly for the rural communities. Conversion of these biodegradable waste waters (both domestic and industrial) into biogas would result in cleaner air as well as efficient waste management system, improving the sanitary conditions of the urban environment. This will lead to socioeconomic benefits with regard to health, income and security of the eco-system threatened by adverse climatic alterations (Ofoefule et al., 2009).

\section{Conclusion}

The results of these studies have shown that the waste waters/ slurries which are pollutants in the areas where they are processed can be sources of useful energy and organic fertilizers by subjecting them to anaerobic digestion for biogas production. The studies further revealed that most of these waste waters on their own are not capable of effective and efficient biogas production since they are mostly found to be acidic in their fresh states. They therefore need to be co-digested with other better producing wastes like animal wastes to enhance their flammable biogas production capabilities. The anaerobic digestion process of these waste waters is expected to be a source of waste management and pollution control.

\section{References}

Allison- Onyechere L.N., U. Ngodi and M.N. Ezike 2007. Anaerobic biotechnology for sustainable waste treatment. A review. J. Res. Bioscience. 3(1): 40-43.

Amuda, O.S and Ibrahim A.O .2006. Industrial waste water system using natural material as adsorbent.Africa Journal of Biotech Vol. (16), pp.1487-1487. 
Anon, 1980. Survival of enteroviruses in rapid-infiltration basins during the land application of wastewater, Annl. Environ. Microbiol. 40:192-200, 1980.

Anon, 1995. "Environmental Estrogens: Consequences to Human Health and Wildlife". IEH assessment. Medical Research Council, Institute for Environment and Health.

Anon. 2005. "Environmental Hazards of the Textile Industry," Environmental Update \#24, published by the Hazardous Substance Research Centers/ South \& Southwest Outreach Program, June 2006; Business Week, June 5, 2005.

Anon. 2010. File:///D:/waste\%20water/water\%20 treatment\%20method.htm, Buzzle.com, intelligent-life on web.

Avnimelech Y., Diab, S. and Kochba, M. 1993. Development and evaluation o a biofilter for turbid and nitrogen rich irrigation water. Wat. Res. 27: 785-790.

Bansode, R.R,Losso J.N, Marshall W.E, Rao, R.M and Portier R.J 2004. Pecan shell-based granulated activated carbon for treatment of chemical oxygen demand (COD), in municipal wastewater. Bioresource Technol. 94: 129-135.

Bhat, P.R., Chanakya, H.N. and Ravindranath, N.H., 2001. Biogas plant dissemination. J. Energy Sustainable Dev. 1: 39 - 41.

Chynoweth, D.P and Owens. M 1991. Biochemical methane potential of municipal solid waste components. Water Science Technology, 27:1-14.

Galambos II, Molina, J.M, Jaray, P., Vatai, G, Bekassy-Molner E. 2004. High organic content industrial wastewater treatment by membrane filtration. Desalination, 162:117-120. http:/ /EzineArticles.com/?expert=Richard_Runion

Lettinga, G., Van Velsen, A.F.M., Hobme, W. de Zeeuw, J. and klapwijk, A. 1980. Use of the upflow sludge blanket (USB) reactor concept for biological waste water treatment especially for anaerobic treatment. Biotech and bioeng. 22:699-734.

Mara, D. and Horan, N., 2003. Water and Wastewater Microbiology, Academic Press.

Mehmet F.S and Hassan Z.S. 2002. Ozone treatment for textile effect and dyes: effect of applied ozone dose, $\mathrm{pH}$ and dye concentration. Journal of Chemical technology and Biotechnology, 77: 842-850.

Naik, A. 2010. Wastewater Treatment Methods. Accessed from http://www.buzzle.com/chapters/chapters.asp. 9th of July 2010.

Namboodri C.G, Perkins W.S and Walsh, W.K. 1994. Decolonizing dyes with chlorine and ozone: Part II, American dyestuff Report, 83: 17-26.

Nasim, A.K, Shaliza,I and Piarapakaran,S. 2004. Elimination of heavy metals from wastewater using agricultural wastes as adsorbents. Malaysian Journal of Science, 23:43-51.

Nomanbhay, S.M, Palanisamy, K. 2005. Removal of heavy metals from industrial wastewater using chitosen coated oil palm shell charcoal. Electronic Journal of Biotechnology, 8:43-53.

Oboh, G. 2005. Isolation and characterization of amylase from fermented cassava (Manihot esculenta Crantz) waste water. African journal of biotechnology. Vol 4 (10), pp 1117-1123. ISSN 1684-5315.

Ofoefule, A.U., Chima, P.U., Nnabuchi, M.N. and Uzodinma, E.O. 2010. Anaerobic batch codigestion of cassava waste water and Swine dung. Nig. J. Solar Energy 20:128 - 132 
Ofoefule, A.U., Ibeto C.N., Uzoma, C.C., Oparaku, O.U. 2009. Biomass Technology: A key driver for improving climate change and socio-economic life in Nigeria. Int. J. Environ. Sci. 5 (1): 54- 58.

Okafor N. 1998. An integrated bio-system for the disposal of cassava wastes. Proceedings of the internet conference on integrated bio-systems, edited by Eng-Leong, F and Tarcisio, D.S. Pp.1-5.

Okieimen, F.E, Ogbeifun, D.E, Navala,G.N, Kumash, C.A. 1985. Binding of copper, Cadmum and Lead by modified cellulosic materials. Bull., Environ. Contam. Toxicol.34: 860-870.

Oparaku, N.F, Mgbenka, B.O and Ibeto, C.N. 2011. Wastewater disinfection utilizing ultraviolet light. Journal of Environmental Science and Technology,4(1):73-78. DOI:10.3923/jest.2011.73.78.

Peres, J.A, Beltran de Heredia, J, Dominguez, J.R. 2004. Integrated Fenton's reagentcoagulation/flocculation process for treatment of cork processing wastewaters. J. .Haz. Mat. 107 (3):115-121.

Preetha, B., Viruthagiri, T. 2005. Biosorption of Zinc (II) By Rhizopus equilibrium and kinetic modeling. African J.Biotechnol. 4(6): 506-508.

Rajeswari, K.R. 2000. Ozonation treatment of textile dyes wastewater using plasma ozonizer, PhD thesis, University of Malaysia, Malaysia.

Runion R. 2009. All about Waste water treatment.

Runion R. 2010. Wastewater - Contamination Sources. http://www-all-about-wastewater-treatment.com/category/wastewater.

Stanislaw L. and Monica G. 1999. Optimization of oxidant dose for combined chemical and biological treatment of textile waste water. Water Research 33, 2511-2516.

Tam,M and Antal M. 1999. Preparation of activated carbons from macademia nut shell and coconut shell by air activation. Ind.Eng. Chem Research, 38:4268-4276.

Uzodinma E.O. and Ofoefule, A.U. 2008. Effect of abattoir cow liquor waste on biogas yield of some Agro-industrial wastes. Sci. Res \& Essay 3 (10): 473-476.

Uzodinma E.O. Eze, J.I. and Onwuka, N.D. 2007b. Energy generation from microbial conversion of treated cassava (manifot utilissima) waste water from garri processing industry. J. Res in Bio Sci 3(1):61-66.

Uzodinma E.O., Ofoefule, A.U., Eze, J.I. and Onwuka, N.D. 2007a. Preliminary studies from blends of palm oil sludge with some Agro-based wastes. Nig. J. Solar. Energy 18: 116-120.

Van Haandel, A.C. and Lettinga, G. 1994. Anaerobic sewage treatment. A practical guide for regions with a hot climate. John Wiley and Sons, Ltd. Chichester ISBN 0-471-951218.

Verstraete, W. deBeer, D., Pena, M., Lettinga, G. and ens, P. 1996. Anaerobic bioprocessing of organic waste. Accepted for Publication in World J. Microbio and Biotech.

Verstraete, W. and Top, E. 1992. Holistic environmental technology. In: Microbial control of pollution. CJ. Fry, G. Gadd, R. Herbert and I. Watson-Crack eds), Cambridge Univ. Press.pp 1-18.

Wolfgang, M. and Axel, H. 2005. An introduction to anaerobic digestion. Seminar presented at the Biowaste. Digesting the alternative seminar UK. 
Xuejun.C, Zhein,S, Xiaolong,Z Yaobo, F and Wenhua,W. 2005. Advanced treatments of textile wastewater for re-use using electrochemical oxidation and membrane filtration. Water SA,Vol. 3(1):127-132. 


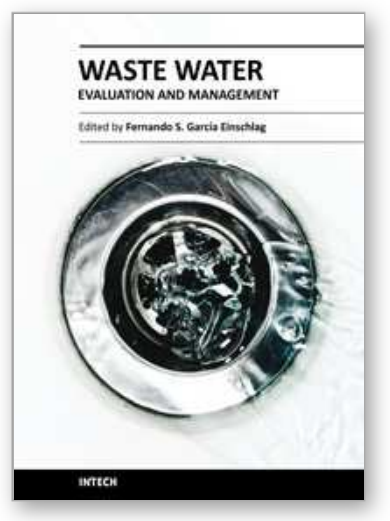

\author{
Waste Water - Evaluation and Management \\ Edited by Prof. Fernando Sebastĩ̃̃ $i n$ GarcÃa Einschlag
}

ISBN 978-953-307-233-3

Hard cover, 470 pages

Publisher InTech

Published online 01, April, 2011

Published in print edition April, 2011

Fresh water resources are under serious stress throughout the globe. Water supply and water quality degradation are global concerns. Many natural water bodies receive a varied range of waste water from point and/or non point sources. Hence, there is an increasing need for better tools to asses the effects of pollution sources and prevent the contamination of aquatic ecosystems. The book covers a wide spectrum of issues related to waste water monitoring, the evaluation of waste water effect on different natural environments and the management of water resources.

\title{
How to reference
}

In order to correctly reference this scholarly work, feel free to copy and paste the following:

Akuzuo Ofoefule, Eunice Uzodinma and Cynthia Ibeto (2011). Waste Water: Treatment Options and its Associated Benefits, Waste Water - Evaluation and Management, Prof. Fernando SebastiÃ $j n$ GarcÃa Einschlag (Ed.), ISBN: 978-953-307-233-3, InTech, Available from: http://www.intechopen.com/books/wastewater-evaluation-and-management/waste-water-treatment-options-and-its-associated-benefits

\section{INTECH}

open science | open minds

\section{InTech Europe}

University Campus STeP Ri

Slavka Krautzeka 83/A

51000 Rijeka, Croatia

Phone: +385 (51) 770447

Fax: +385 (51) 686166

www.intechopen.com

\section{InTech China}

Unit 405, Office Block, Hotel Equatorial Shanghai

No.65, Yan An Road (West), Shanghai, 200040, China

中国上海市延安西路65号上海国际贵都大饭店办公楼 405 单元

Phone: +86-21-62489820

Fax: +86-21-62489821 
(C) 2011 The Author(s). Licensee IntechOpen. This chapter is distributed under the terms of the Creative Commons Attribution-NonCommercialShareAlike-3.0 License, which permits use, distribution and reproduction for non-commercial purposes, provided the original is properly cited and derivative works building on this content are distributed under the same license. 